\title{
A Study on Child Values of Chinese Mothers Born in the 1980s and Their Expenses for Raising Children
}

\section{0년대에 출생한 중국 어머니들의 자녀 가치관과 자녀 양육을 위한 지출}

\author{
Ning Yang ${ }^{1}$, Heykyong Choi $^{2}$ \\ 양녕 ${ }^{1}$, 최혜경 ${ }^{2}$ \\ ${ }^{1}$ Graduate student, Department of Consumer Studies, Ewha Womans University, Korea, \\ wdw4599@gmail.com \\ ${ }^{2}$ Professor, Department of Consumer Studies, Ewha Womans University, Korea, chk@ewha.ac.kr
}

Corresponding author: Hyekyong Choi

\begin{abstract}
This research is aimed at classifying the views of Chinese mothers from 80 s generation on child values, while exploring whether different types of child values will be related to variations in the expenditure amount and items in both educational and non-educational child support areas. For the study, the 80s generation mothers who live in the vicinity of Beijing and Tianjin were collected, and the results of this research are as follows. First, the respondents of the study were classified into 4 child values groups' sentiment type', 'family function type', 'future investment type' and 'personal achievement type', based on 4 categories of child values; 'emotional value', 'economic value', 'social value', 'family inheritance and continuance value'. Second, The expenditure amount and items 80 s generation mothers spend for their children were varied according to their child values types, expecially in the amount of private education fees and non-educations expenditure such as preferred school types, bank savings, entertainment expenditure for their children. 'Sentiment type' mothers and 'future investment type' mother show contrasts in their expenditure patterns. 'Sentiment type' mothers spent money on leisure and cultural life with their children more than mothers with other child values, while 'future investment type' mothers spent more money for their children on private education, other necessary expenditure, and financial products/services.
\end{abstract}

Keywords: Chinese 80s Generation, Child Value Types, Child Rearing Expenditure, Child Education Expenditure

요약: 본 연구는 중국 빠링허우 세대 (1980년대에 출생한 세대)의 자녀 가치관 유형에 따라 그들의 자녀 양육 및 교육 지출에 차이가 있는지를 살펴보는 데에 목적이 있다. 이를 위해 북경과 천진에 거주하고 자녀가 있는 빠링허우 세대 어머니들 280 명을 대상으로 하여, 이들의 자녀 가치관이 어떤 유형으로 분류되는지, 그리고 자녀 가치관 유형에 따라 자녀 양육 및 교육의 지출유형과 지출액에 차이를 보이는지를 규명하고자 하였다. 본 연구의 결과 첫째, 빠링허우 세대 어머니들의 자녀 가치관은 '정서적 가치' , '경제적 가치', '가족 계승 및 연속 가치' , '사회적 가치' 등 4가지 가치 요인의 차원에서 '정서집중형' , ‘미래투자형' , ‘가족 기능형', ‘개인성취형' 등 4개 가치 유형 집단으로 분류되었다.

Received: June 10, 2021; $1^{\text {st }}$ Review Result: July 25, 2021; $2^{\text {nd }}$ Review Result: September 7, 2021 Accepted: October 31, 2021 
둘째, 빠링허우 세대 어머니들의 자녀 가치관 유형에 따라 자녀 양육 및 교육의 지출액과 지출내용에 차이가 나타났다. 사교육비, 기타 자녀 양육비, 자녀를 보내고 싶은 학교의 특성, 그리고 자녀를 위한 은행예금 및 여가 등의 지출 여부에서 차이를 보였다. 특히 ‘정서집중형' 어머니들과 '미래투자형' 어머니들이 지출에서 대조적인 특징을 보였다. ‘정서집중형' 어머니들은 교육이나 금융상품보다는 여행이나 문화생활 관련 제품이나 서비스를 다른 유형의 어머니들보다 가장 많이 구매한다고 보고하였다. 반면 '미래투자형' 어머니들은 자녀를 위한 사교육 및 교육 외 필요 지출 그리고 금융상품에 지출을 가장 많이 하는 것으로 나타났다.

핵심어: 빠링허우세대, 자녀가치관, 자녀양육지출, 자녀교육지출

\section{1. 서론}

빠링허우 (八零后) 는 1979년 중국에서 '산아제한 정책' (1가구 1자녀 정책)을 실시한 이후 1980 1989년에 출생한 사람을 지칭하는 말이다. 중국에서 1차 외동아들 또는 외동딸로 태어난 빠링허우 세대는 부모 세대와 달리 중국 내 개혁-개방 정책 이후에 시장경제를 전면으로 받아들였기 때문에 어렸을 때부터 급속한 경제 성장의 혜택을 누리며 자라 일명 ‘소황제·소공주' 라고 일컬어지기도 한다. 이들의 사고방식은 경제 성장뿐 만 아니라 인터넷의 발달과 정보화, 글로벌화라는 시대적 배경을 통해 더 큰 전환기를 맞게 되었다[1]. 빠링허우는 가치관과 경제 체제에서 전혀 다른 두 시대를 모두 다 경험하면서 모순된 가치관과 생활방식 사이에서 혼란을 겪게 되었다[1].

중국에서 빠링허우에 대한 관심과 그에 따른 연구가 지속해서 이루어져 왔으나, 현재 성인기에 있는 빠링허우의 현실을 반영한 연구들은 많지 않다. 본 연구는 부모가 되어 아이 노예( ‘孩奴' )로 불리는 빠링허우들의 자녀 양육 특성에 관심을 둔다. 중국 사회는 경제발전에 따른 사회구조의 변화를 경험하게 되었고, 특히 1980년대에 산아제한 정책이 시행되면서 중국인의 자녀 가치에 변화가 일어났다[2][3]. 경제발전에 따른 여성의 교육 수준 향상, 여성 취업의 증가 등과 같은 여성 역할관의 변화 역시 자녀 가치에 영향을 미쳤을 것으로 판단된다[4]. 이전에는 자녀의 수에 집중했다면 자녀의 소질과 정서적 가치에 대해 더 중요시하게 된 것이다. 자녀 가치는 개인의 출산 동기를 구성하는 데 큰 역할을 하는 중요한 개념일 뿐 아니라 자녀 양육 특성에도 영향을 미친다[5-8]. 한편 자녀에 대해 지각한 가치는 자녀를 위한 지출 행동에 영향을 미칠 수 있을 것이다[9]. 2021년 KOTRA에서는 중국의 세 가지 소비 계층이 대두되었다고 하면서, 이전 세대들과 비교하여 빠링허우는 자녀에 투자를 많이 할 가능성이 높다고 밝혔다[10].

빠링허우는 특수한 역사적 시대에서 성장해 왔기 때문에 그 세대의 사람들만의 독특한 특성을 보이고, 자녀를 양육하는 데에 자기만의 새로운 관념을 가지고 있다. 빠링허우들은 개방적이고 포용하는 사회에서 성장해 왔기 때문에, 양육방식에서도 자녀를 존중하는 편이고 자녀가 밝고 건강하게 성장하는 것을 더 중시하여 민주적인 양육방식을 채택하는 것으로 나타났다[2]. 구체적으로 빠링허우 부모들은 자녀의 전반적인 발전에 중점을 두고, 자녀의 의견을 존중하며, 자녀의 요구를 자세히 들어준다[11][12]. 하지만 사회 현실의 압력 때문에 이들의 자녀의 학습에 대한 욕구는 
여전히 높은 편이다. 이로 인하여 빠링허우 부모들에게 모순적인 심리 상태를 초래하여, 자녀가 놀 수 있는 시간이 더 많아지기를 희망하지만 자녀가 어릴 때부터 조기 교육이나 사교육을 많이 시키는 편이기도 한 것이다[2][13][14].

빠링허우 세대는 다른 연령층보다 높은 소비능력을 지니고 있고 경제활동인구의 주력계층이 되었다[14]. 빠링허우 세대는 대부분이 자기의 소득 수준에 낙관적인 태도를 가지고 있기 때문에 구매력이 다른 연령층보다 높은 편이다. 그러나 지금까지의 연구들이 빠링허우 세대의 개인적인 소비에 관심을 두고 진행되었다면, 부모가 된 이 세대가 미래세대를 위해 어떻게 소비하고 지출하는지를 보여주는 연구들은 많지 않다. 이들 연구에 따르면, 빠링허우 세대인 부모들은 우수하고 신뢰할만한 품질의 제품과 서비스를 자녀에게 제공하고자 한다. 중국시장에서 빠링허우의 자녀 양육비용은 점점 더 고급화되고 액수도 계속 증가하는 추세를 보이고 있다[15]. 자녀 양육비용이 계속 올라가는 이유는 첫째, 생활 수준이 높아짐에 따라 구매력이 높아졌기 때문이고, 둘째, 부모들이 인터넷을 통해 육아경험을 공유하는 것을 즐기며 서로에게 모방 및 비교를 통해 영향을 주고 받고 그 가운데 경쟁심이 생기기 때문이다. 셋째, 부모의 감성적 소비로 인해 맹목적인 구매행동을 초래하기 때문이다[2][9]. 또한 빠링허우가 자녀의 교육을 위해 지출하는 비용은 빠링허우 세대 소비 총액의 절반이상 수준인 $55 \%$ 를 차지했다[14][16]. 자녀를 위한 교육 소비는 문구 및 책 등의 구매, 교통비, 정규학교 등록금, 사교육비 지출 등을 포함하고, 서로 모방하거나 상향 비교하는 경향을 보이며, 교육을 위한 지출이 계속 올라가는 경향을 보이고 있다. 대부분의 빠링허우들은 교육 지출로 인한 스트레스를 많이 받는 편이며, 교육기금, 교육대출 등 금융 상품의 구매를 통해서 스트레스를 완화시키기도 한다[16][17].

이처럼 빠링허우 세대는 소비 시장의 주력군이자 자녀 투자 가능성이 높은 세대이므로, 빠링허우의 자녀양육가치와 자녀를 위한 지출 특성을 연구하는 것은 중요한 의미가 있을것이다.

\section{2. 연구방법}

본 중국 빠링허우 어머니들을 대상으로 하여 빠링허우 어머니의 자녀 가치관 유형이 어떻게 분류되고, 자녀 가치관 유형에 따라 자녀를 위한 교육 지출, 지출항목, 지출액, 직접 구매하는 제품 및 서비스에서 차이가 있는지를 알아보고자 하였다. 구체적인 연구 문제는 다음과 같다.

연구 문제1. 중국 빠링허우 세대 어머니의 자녀 가치관 유형은 어떻게 분류되는가?

연구 문제 2 . 중국 빠링허우 세대 어머니의 자녀 가치관에 따라 자녀 양육과 교육을 위한 지출에 차이를 보이는가?

\section{1 연구대상}

본 연구는 중국 현재 북경이나 천진에 거주하고 자녀를 가지고 있는 빠링 허우 세대 어머니를 연구대상으로 하였다. 조사는 중국 온라인 설문 홈페이지를 이용하여 2017년 10월 25일부터 11월 8일까지 2주간 온라인 설문 조사를 실시하였다. 설문지는 총 330 부를 수집한 후 누락된 문항이 있거나 응답이 성실하지 않은 50 부의 설문지를 제외한 280부를 분석에 사용하였다.

본 연구의 대상들의 사회인구학적 특성은 [표 1]에 제시되어 있다. 연구 대상들의 
연령은 평균 33.5 세로서, 32세 38세가 $73.2 \%$ 로 가장 많은 비중을 차지하였다. 대부분이 기혼자이고 $(97.5 \%)$, 대졸 이상이 응답자 $79.3 \%$, 남편 $75.7 \%$ 으로 전반적으로 학력이 높고, 맞벌이 부부인 경우가 대부분이었다. 가계 월평균 소득은 $10,000-15,999$ 위엔 이하가 30.7\%로 가장 많았고, $16,000-21,999$ 위엔과 22,000 위엔 이상이 각각 $25.4 \%$, $25.0 \%$ 로 비슷한 비중을 차지했으며, 9,999 위엔 이하는 $18.9 \%$ 로 가장 낮게 나타나는데, 이를 통해서 대부분의 연구대상자가 일정한 경제적 능력을 갖추고 있다는 사실을 유추할 수 있다. 연구대상자의 자녀수는 한 명인 경우가 $75.4 \%$ 로 대부분의 응답자가 자녀를 하나만 가지는 것을 알 수 있었다. 자녀의 평균 연령은 5.5 세로서, 대부분 유아원/유치원이나 초등학교에 다니고 있었다.

[표 1] 연구대상자의 주요 사회인구학적 특성

[Table 1] Socio-Demographic Characteristics of Respondents

\begin{tabular}{|c|c|c|c|c|}
\hline 변인 & 구분 & $\mathrm{N}$ & 비율 (\%) & $\begin{array}{c}\text { 평균 } \\
\text { (표준편차) }\end{array}$ \\
\hline \multirow{3}{*}{ 연령 } & 29-31 세 & 75 & 26.8 & \multirow{3}{*}{$\begin{array}{c}33.5 \\
(2.562)\end{array}$} \\
\hline & 32-34 세 & 103 & 36.8 & \\
\hline & 35-38 세 & 102 & 36.4 & \\
\hline \multirow{2}{*}{ 결혼상태 } & 기혼 & 273 & 97.5 & \\
\hline & 이혼 또는 별거 & 7 & 2.5 & \\
\hline \multirow{5}{*}{$\begin{array}{l}\text { 응답자 } \\
\text { 최종학력 }\end{array}$} & 무학 & 5 & 1.8 & \\
\hline & 고등학교 졸업 이하 & 10 & 3.6 & \\
\hline & 전문대졸업 & 43 & 15.4 & \\
\hline & 대학졸업 & 179 & 63.9 & \\
\hline & 대학원 이상 & 43 & 15.4 & \\
\hline \multirow{7}{*}{ 응답자 직업 } & 관리직 & 51 & 18.2 & \\
\hline & 사무직 & 85 & 30.4 & \\
\hline & 전문직 & 60 & 21.4 & \\
\hline & 기술직 & 36 & 12.9 & \\
\hline & 서비스/판매직 & 22 & 7.9 & \\
\hline & 자영업,농업/임업/어업/목축업,기타 & 20 & 7.1 & \\
\hline & 전업주부 & 6 & 2.1 & \\
\hline \multirow{4}{*}{$\begin{array}{c}\text { 남편 } \\
\text { 최종학력 }\end{array}$} & 고등학교 졸업 이하 & 19 & 6.8 & \\
\hline & 전문대졸업 & 49 & 17.5 & \\
\hline & 대학졸업 & 164 & 58.6 & \\
\hline & 대학원 이상 & 48 & 17.1 & \\
\hline \multirow{6}{*}{ 남편 직업 } & 관리직 & 87 & 31.1 & \\
\hline & 사무직 & 50 & 17.9 & \\
\hline & 전문직 & 38 & 13.6 & \\
\hline & 기술직 & 50 & 17.9 & \\
\hline & 서비스/판매직 & 20 & 7.1 & \\
\hline & 자영업,농업/임업/어업/목축업,기타 & 35 & 12.5 & \\
\hline
\end{tabular}




\begin{tabular}{|c|c|c|c|c|}
\hline & 전업주부 & 0 & .0 & \\
\hline \multirow{4}{*}{$\begin{array}{l}\text { 가계 월 } \\
\text { 평균 소득 }\end{array}$} & 9999 위엔 미만 & 53 & 18.9 & \\
\hline & 10000 위엔 이상-15999 위엔 & 86 & 30.7 & \\
\hline & 16000 위엔 이상-21999 위엔 & 71 & 25.4 & \\
\hline & 22000 위엔 이상 & 70 & 25.0 & \\
\hline \multirow{3}{*}{ 총 자녀수 } & 1 명 & 211 & 75.4 & \multirow{3}{*}{$\begin{array}{c}1.3 \\
(.572)\end{array}$} \\
\hline & 2 명 & 53 & 18.9 & \\
\hline & 3 명 & 16 & 5.7 & \\
\hline \multirow{5}{*}{$\begin{array}{c}\text { 첫번째 자녀 } \\
\text { 연령 }\end{array}$} & 0-3 살 & 77 & 27.5 & \multirow{5}{*}{$\begin{array}{c}5.5 \\
(3.052)\end{array}$} \\
\hline & 4-6 살 & 113 & 40.3 & \\
\hline & 7-9 살 & 63 & 22.5 & \\
\hline & $10-12$ 살 & 20 & 7.2 & \\
\hline & 13 살 이상 & 7 & 2.6 & \\
\hline \multirow{5}{*}{$\begin{array}{c}\text { 첫번째 자녀 } \\
\text { 학교 }\end{array}$} & 미취학 & 51 & 18.2 & \\
\hline & 유아원/유치원 & 117 & 41.8 & \\
\hline & 초등학교 & 100 & 35.7 & \\
\hline & 중학교 & 10 & 3.6 & \\
\hline & 고등학교 & 2 & .7 & \\
\hline
\end{tabular}

\section{2 측정도구 및 분석방법}

본 연구의 측정 도구는 설문지로서, 연구대상자의 사회·인구학적 특성, 연구대상자 자녀의 일반적인 사항, 자녀를 위한 교육 지출, 교육 소비를 제외할 때 자녀를 위할 필요 지출(지출항목, 지출액, 구매하는 제품 및 서비스), 그리고 자녀 가치척도를 포함하고 있다. 자녀 가치관을 측정하기 위한 문항들은 ANKANG[5]의 자녀 가치척도를 참고하였다. 8 가지의 자녀 가치 요인, 총 52 개 문항으로 구성되어 있으며 5점 척도로 측정하게 되어있는데, 본 연구를 위해 요인 간 문항 중복성, 빠링허우 세대에의 적합성, 본 연구의 목적 등을 고려하여 52 개 문항 중 22 개 문항을 채택하였다. 자녀 가치관 요인을 분류하기 위해서 주성분 분석과 탐색적 요인분석을 하였고, 22 개의 문항을 대상으로 하여 4 개의 요인을 추출하였다. 요인1은 '정서적 가치' 로서 자녀로 인한 심리적 만족 측면을 나타내는 8개 문항으로 구성되며, 고유값은 8.179로 전체분산의 $25.200 \%$ 를 차지했다. 요인2는 자녀를 통한 경제적, 도구적 도움에 대한 기대를 나타내는

'경제적 가치' 로서 4 개 문항으로 구성되며 고유값은 4.485 로 전체분산의 $15.799 \%$ 를 차지했다. 요인3은 자녀가 가족의 전통 및 명예를 확장하고 공고히 한다는 기대로서 '가족 계승 및 연속 가치' 를 나타내며 4개 문항, 고유값 1.324 , 전체분산의 $13.992 \%$ 를 설명한다. 요인 4 는 부모의 사회적 책임감을 나타내는 5 개 문항을 포함하는 '사회적 가치' 로서, 고유값은 1.106 로 전체분산의 $13.621 \%$ 를 설명한다.

수집된 자료는 SPSS WindowS 24.0을 이용하여 분석하였다. 연구대상의 일반적 특성을 파악하기 위해 기술통계분석을, 자녀 가치관 유형을 분류하기 위해 신뢰도 분석(Cronbach' s a 값)과 $\mathrm{K}$-평균 군집 분석을 실시하였다. 그리고 자녀 가치관 유형에 따른 자녀 양육 및 지출 차이를 보기 위해 교차 분석과 카이제곱 검증, 일원 배치 분산분석, 사후 검정을 실시하였다. 


\section{3. 연구결과}

\section{1 자녀 가치관의 유형}

자녀 가치관 4 개 요인을 기반으로 군집분석을 실시하였다. 군집의 수를 2 개에서 6 개로 지정하여 $\mathrm{K}$-평균 군집분석을 실시한 결과, 군집수가 4 개인 경우 해당빈도와 점수의 평균값이 상대 적 합리적인 패턴을 갖추고, 균형성과 내용 관련성 측면에 의미있는 결과를 보여주며, 군집 간의 특성이 비교적 뚜렷이 나타나 최종적으로 4 가지 집단으로 분류하였다.

[표 2] 자녀가치관 유형에 따른 연구대상자 군집 분류

[Table 2] Ttypes of Child Value Groups Based on K-means Cluster Analysis

\begin{tabular}{|c|c|c|c|c|c|}
\hline \multirow[t]{2}{*}{ 요인 } & $\begin{array}{c}\text { 군집 } 1 \\
\text { 정서집중형 } \\
(n=50)\end{array}$ & $\begin{array}{c}\text { 군집 } 2 \\
\text { 가족기 능형 } \\
(n=98)\end{array}$ & $\begin{array}{c}\text { 군집 } 3 \\
\text { 미래 투자형 } \\
(n=92)\end{array}$ & $\begin{array}{c}\text { 군집 } 4 \\
\text { 개인 성취형 } \\
(\mathrm{n}=29)\end{array}$ & \multirow[t]{2}{*}{$\mathrm{F}$} \\
\hline & M (duncan) & M (duncan) & M (duncan) & M (duncan) & \\
\hline 정서적가치 & 4.31 (a) & 4.29 (a) & $4.53(\mathrm{~b})$ & 4.69 (b) & $10.605^{* * *}$ \\
\hline 경제적가치 & $2.0(\mathrm{a})$ & 2.78 (b) & 4.17 (c) & $2.21(\mathrm{a})$ & $186.631^{* * *}$ \\
\hline 계승 및 연속 & 1.86 (a) & 3.48 (b) & $4.22(\mathrm{c})$ & $1.99(\mathrm{a})$ & $220.083^{* * *}$ \\
\hline 사회적 가치 & 2.46 (a) & $3.6(\mathrm{~b})$ & 4.37 (c) & 4.25 (c) & $145.287^{* * *}$ \\
\hline
\end{tabular}

$* * * \mathrm{p}<.001$

[표 2]를 보면 정서적 가치가 전반적으로 높게 나타나는 가운데, 군집3을 제외한 다른 군집들이 경제적 가치가 모두 다 낮은 것으로 나타났다. 군집 1 은 다른 군집에 비해 비교적 모든 자녀 가치가 낮게 나타난다. 같은 군집 내에서는 자녀에 대한 정서적 가치가 다른 가치들에 비해 상대적으로 높아 자녀 가치 유형에서 '정서집중형' 으로 볼 수 있다. 군집 2 는 다른 군집과 비교했을 때 정서적 가치가 가장 낮은 한편, 전반적으로 다른 자녀 가치 요인들은 중간 정도의 수준이다. 이 유형에 속한 사람들은 자녀를 통한 가족의 연속 및 전통이나 재산의 전승을 비교적 가치있게 생각하고, 사회적인 의미도 중요하게 생각한다는 점에서 '가족기능형' 이라고 명명하였다. 군집 3 은 다른 군집과 비교했을 때 모든 자녀 가치에 있어 높은 점수를 보였다. 특히 경제적, 가족 계승 및 연속, 시회적 요인이 다른 집단에 비해 가장 높게 나타났으며, 정서적 요인도 두번째 순위를 차지했다. 이들은 다양한 측면에서 자녀의 가치를 부여하고 자녀에 대해 많이 투자한다고 보아 ‘미래투자형' 으로 명명하였다. 군집 4는 수가 적은 편인데, 다른 군집과 비교하여 정서적 가치, 사회적 가치가 비교적 높고, 경제적 가치, 가족 계승 및 연속 가치는 비교적 낮다. 이 군집에 속한 사람들이 자녀를 키움으로써 심리적 만족이나 안정감을 기대하고, 자녀를 낳고 양육하는 과정에서 사회로부터 인정을 받고 자아 완성을 실현할 수 있기 바란다. 이렇기 때문에 군집 4 를 '개인성취형' 이라고 하였다.

\section{2 자녀 가치관 유형에 따른 자녀 양육 및 교육을 위한 지출}

자녀 가치관 유형에 따른 자녀 양육 및 교육 지출을 알아보기 위해 교차분석과 
카이제곱 검증을 실시하였다.

[표 3] 자녀가치관 유형에 따른 집단 간 자녀를 위한 교육지출 특성

[Table 3] Educational and Non-educational Child Support Expenditure According to Child Value Groups

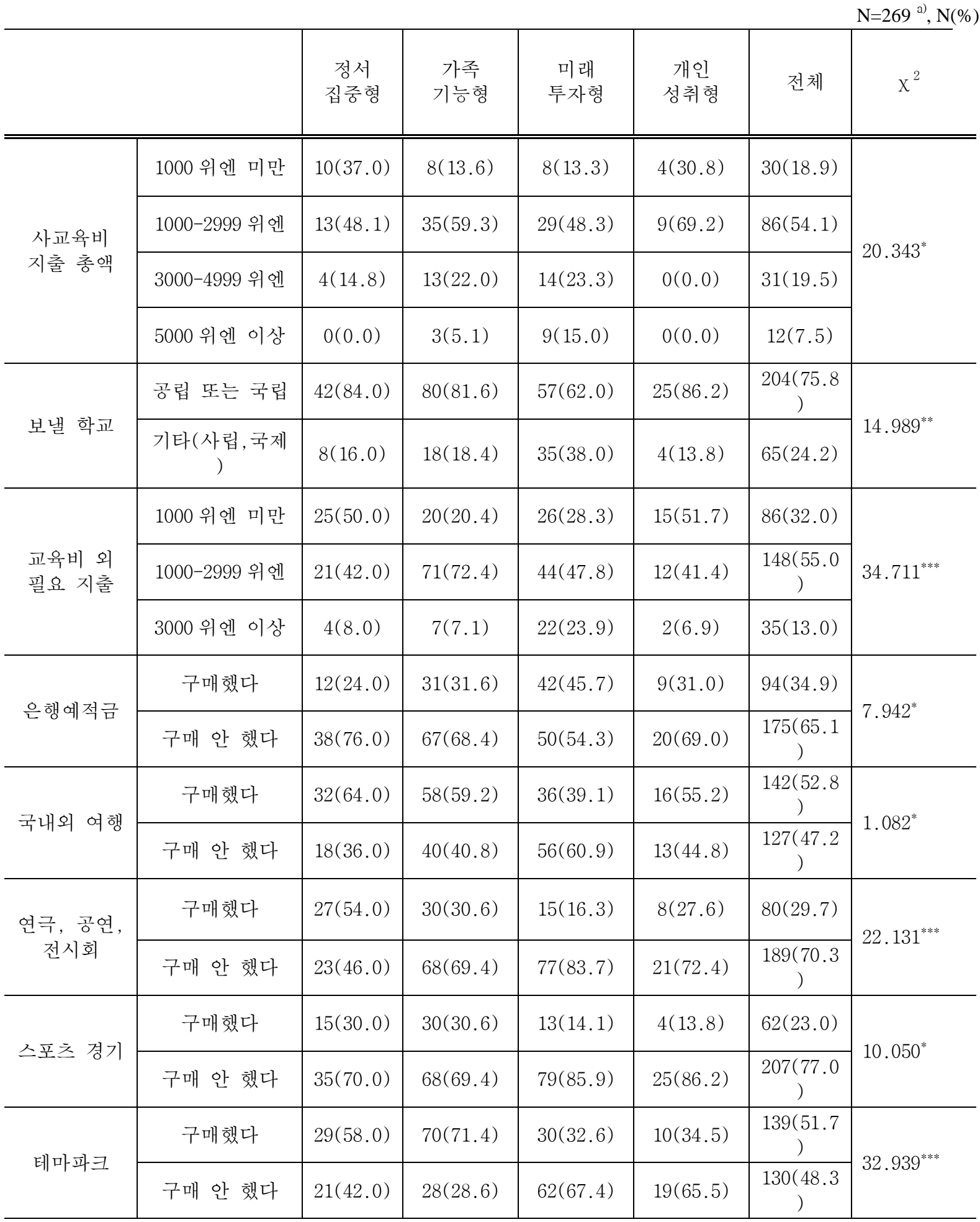

" $\mathrm{p}<.05,{ }^{* *} \mathrm{p}<.01,{ }^{* * *} \mathrm{p}<.001$

a)연구대상 중 사교육비를 지출하는 어머니들만을 대상으로 분석하여 전체 합계가 다름 $(\mathrm{N}=159)$. 
먼저 교육 지출과 관련하여 사교육비 지출 총액과 자녀가 진학하면 보내려는 학교에서 유의미한 차이가 나타났다. '미래투자형' 어머니들은 자녀를 위한 사교육비 지출이 가장 많고, 자녀를 사립학교나 국제학교로 진학시키고 싶어하는 경향이 가장 높았다. 반면 ‘개인성취형' 어머니들의 사교육비 지출이 가장 낮으며 사립 학교나 국제학교에 대한 선호도가 가장 낮았다. 미래투자형은 미래의 이익을 고려하여 자녀의 여러 가지 가치에 대한 기대에 미칠 수 있도록 자녀를 더 우수한 사람으로 교육시켜 자녀의 교육에 투자를 많이 한다는 것을 알 수 있다. 개인성취형은 심리적 감정과 자아에 더 집중하기 때문에 자녀의 교육에 그다지 집착하지 않는다고 해석할 수 있다.

정규학교 등록금이나 사교육비를 제외하고 다른 부문에서 자녀를 위한 지출 액에서도 자녀 가치관 유형별로 유의한 차이를 보였다. '가족기능형' 과 '미래투자형' 어머니들이 ‘정서집중형' 과 '개인성취형' 어머니들에 비해 자녀를 위한 지출액이 더 높은 편으로 나타났다. 지출항목을 보면, ‘미래투자형' 은 은행 적금 및 예금을 드는 비율이 다른 군집의 어머니들에 비해 높았다. 그러나 자녀를 위한 여행이나 문화생활을 하는 비율은 4개 군집 중 가장 낮았다. '미래투자형' 어머니들은 자녀에 대한 감정적 투자보다 객관적이고 실질적인 투자를 더 선호하기 때문인 것으로 해석할 수 있다. 반대로 ‘정서집중형' 은 국내외 여행과 문화 생활의 항목을 가장 많이 구매하는 것으로 나타났는데, 이 가치관 집단의 어머니들은 심리적 만족에 중점을 두고 자녀와의 신체적이나 감정적 상호작용이 많기 때문에 자녀와 함께 여행을 많이 다니고, 자녀를 테마파크로 데려가거나 같이 영화, 공연 등을 구경하고 자녀와 같이 즐거운 시간을 보내는 것으로 볼 수 있다.

\section{4. 결론}

본 연구에서는 빠링허우 어머니들의 자녀 가치관이 어떤 특성을 지니고 있으며, 자녀 가치관에 따라 자녀 양육 및 교육을 위한 지출에 차이를 보이는지에 관심을 두었다. 연구 결과 연구대상인 빠링허우 어머니들은 공통적으로 자녀에 대한 정서적 가치는 높은 한편 자녀에 대한 경제적 가치는 대체적으로 낮은 특성을 보였다. 연구대상자들이 자녀를 키움으로써 심리적 만족과 감정적 안정감을 중요하게 생각하고 경제적 이익에 대해 그다지 바라지 않는 것을 알 수 있으며, 이는 빠링허우 어머니들의 자녀 가치관의 특징이라고 할 수 있다.

그러나 이들 어머니들은 동일 시대적 배경을 공유하는 같은 세대임에도 불구하고 세대 내에서 다른 자녀 가치관 유형을 보이는 집단들이 존재하는 것으로 나타났다. 정서적 가치, 경제적 가치, 사회적 가치, 가족 계승 및 연속 가치를 중심으로 자녀 가치관 유형을 구분할 때, ‘정서집중형' , ‘가족기능형', ‘미래투자형' , ‘개인성취형' 의 4 개의 서로 다른 군집으로 분류되었다.

또한, 자녀 가치관 유형에 따라 자녀를 위한 양육이나 교육 지출도 다른 것으로 나타났다. 특히 ‘정서집중형' 과 '미래투자형' 은 서로 대조적인 특성을 보였는데, 먼저 ‘정서집중형' 은 교육이나 금융상품보다는 여행이나 문화생활 관련 제품이나 서비스를 다른 유형의 어머니들보다 가장 많이 구매한다고 보고하였다. '정서집중형' 어머니들은 심리적 만족을 중요하게 생각하여 자녀와 즐거운 시간을 보내고 정서적으로 교류하기 위한 방향으로 지출을 하는 경향이 크다고 해석할 수 있다. '미래투자형' 어머니들은 자녀를 위한 사교육 및 교육 외 필요지출 그리고 금융상품에 지출을 가장 
많이 하는 반면, 자녀의 여가나 문화생활을 위한 지출은 가장 적게 하는 유형으로 나타났다. 이들은 자녀에게 기대할 수 있는 여러 가치를 모두 중요하게 생각하고 자녀를 위한 투자로서 감성적 소비 보다는 상대적으로 효용울 따지는 지출을 하는 것으로 볼 수 있다.

본 연구는 중국 소비 시장의 주소비계층이자 자녀 양육비를 지출하는 비율이 높은 세대인, 빠링허우 세대 어머니의 자녀에 대한 지출 특성을 단 - 장기적으로 탐색했다는 중요한 의의를 가진다. 또한, 향후 이들 세대를 타깃으로 한 중국 소비트렌드 이해, 아동관련 산업 마케팅 전략, 시장정책 및 소비자 교육의 자료로도 활용 가능할 것이다.

본 연구의 한계점 및 향후 연구방향에 대해 제언을 하면 다음과 같다. 첫째, 본 연구에서는 코로나 팬데믹 이전의 중국소비자 자료를 분석하였다. 코로나 팬데믹은 소비자들의 라이프스타일 트렌드에 커다란 변화를 가져왔을 것으로 전망하고 있기 때문에, 팬데믹 이후에 빠링허우 어머니들을 포함하여 중국 소비자들의 자녀 양육관련 가치와 소비 행동에 어떤 변화가 있었는지를 탐구하는 후속 연구가 필요할 것이다.

둘째, 현재의 빠링허우 세대는 그 경제적 축적이 아직 충분하지 않을 뿐만 아니라 자녀가 대부분 어리기 때문에 자녀를 위한 교육 지출 규모와 구매하는 제품 및 서비스 범위에 한계가 있을 것이다. 빠링허우 세대의 자녀가 자라면서 동시에 이 세대의 경제적 능력이 어는 정도 향상되면 자녀의 유학이나, 자녀를 위한 금융적 투자 등에 더 뚜렷한 차이가 나타날 것이다.

셋째, 본 연구는 빠링허우 세대의 자녀양육 특성을 자녀 가치관의 측면에서 살펴보았지만 양육 태도에 대해서는 측정하지 않았다. 따라서 향후의 연구에서는 빠링허우 세대의 양육 태도를 측정하여 자녀 가치관 및 양육 태도가 어떤 관계가 있는지를 살펴보면 이 세대에 대한 문헌자료를 더 풍부하게 해 줄 수 있을 것이다.

\section{References}

[1] E. Lee, Consumer Culture of Young White-collar Shanghainese: Social Traits of Consumption and the Formation of New Relationships, Korean Cultural Anthropology, (2011), Vol.44, No.2, pp.139-177, UCI: G704000360.2011.44.2.007

[2] L. Ma, The Impact of Paringhou Parents' Child Rearing Patterns on the Child's Self Care Abilities, Shenyang Normal University, Master's Theisis, (2013)

[3] W. Zhang, A Comparative Study of Parenthood Concept and Child Rearing Behaviors between Chinese and American Parents from Cultural Perspectives, Southwest Petroleum University, Master's Thesis, (2014)

[4] J. E.Nam, J. H. Chung, An Analysis of Articles on the View on Childbearing of Korean Parents in Age Low Birth - with Emphasis Focused on Chosun Daily Newspaper Articles from 2000 to 2010, The Korean Journal Child Education, (2012), Vol.21, No.1, pp.109-124, UCI : G704-001652.2012.21.1.017

[5] B. Ankang, Actual Survey of Child Value Questionnairs, Tianjin Normal University, Master’s Thesis, (2009)

[6] J. R. Udry, Biosocial Models of Low-Fertility Societies, Population and Development Review, (1996), Vol.22, pp.325336, DOI: $10.2307 / 2808017$

[7] H. P. Kohler, J. L. Rodgers, K. Christensen, Is Fertility Behavior in our Genes? Findings from a Danish Twin Study, Population and Develompent Review, (1999), Vol.2, No.2, pp.252-288.

[8] C. Kagitcibasi, B. Ataca, Value of Children, Family Change, and Implications for the Care of the Elderly, Cross-Cultural Research, (2015), Vol.49, No.4, pp.374-392, DOI: 10.1177/1069397115598139 
[9] B. Y. Lee, H. J. Cheon, A Study on the Effects of Mothers' Value of Children and Imported Famous Brands on Mothers' Purchasing Behavior of Imported Famous Care Products: Focusing on Thirties and Forties Mothers, Consumer Policy and Education Review, (2012), Vol.8, No.3, pp.27-46, UCI : G704-SER000010337.2012.8.3.001

[10] https://m.news.kotra.or.kr/user/globalAllBbs/kotranews/album/2/globalBbsDataAllView.do?dataIdx=121233, Jun 05 (2021)

[11] L. Su, A Study of the Impact of Paringhou Parents on their Children's Socialization, Central China Normal University, Master's Thesis, (2016)

[12] S. Jiang, The Status Quo of Child-Rearing Practices of Parents Born in the 1980s and Relation to Parenting Locus of Control for Children, Advances in Psychology, (2012), Vol.2, No.4, pp.224-228, DOI: 10.4236/AP.2012.24035

[13] N. Liu, The consumption view of the new generation of Chinese post-80s parents, Economist, (2014) Vol.11, pp.49$50, \mathrm{pp} 53$.

[14] L. Xiashoan, Purchasing Hope: The Consumption of Children's Education in Urban China, The Journal of Chinese Sociology, (2019), Vol.6, No.1, pp.1-26, DOI: 10.1186/s40711-019-0099-8

[15] J. Yeo, Diversity of Chinese Little Emperors (80s genearation) and Marketing Strategies, CHINDIA PLUS, (2010), Vol.46, pp.12-13.

[16] J. S. Podoshen, L. Li, J. Zhang, Materialism and conspicuous consumption in China: a cross-cultural examination, International Journal of Consumer Studies, (2011), Vol.35, No.1, pp.17-25, DOI: 10.1111/j.1470-6431.2010.00930.x

[17] Y. Chen, Paringhou Parents's Education Expenditure "Far Ahead", Chinese Stock Journal, (2017), Vol.A07, pp.1-2. 